\title{
Effects of water salinity and nitrogen fertilization on the growth and yield of 'BRS Gabriela' castor beans
}

\section{Efeitos da salinidade da água e adubação nitrogenada sobre o crescimento e produção da mamoneira 'BRS Gabriela'}

\author{
João Batista dos Santos ${ }^{1 *}$; Hans Raj Gheyi ${ }^{2}$; Klebson Santos Brito ${ }^{3}$; \\ Diego Azevedo Xavier"; Geovani Soares de Lima ${ }^{5}$; \\ Cruz Ramón Marenco Centeno ${ }^{6}$; Manassés Mesquita da Silva ${ }^{7}$
}

\begin{abstract}
The castor bean has attracted the attention of many farmers as an alternative crop for the National Program of Biofuel and its extensive use in the ricinochemical industry. The crop requires large planting areas to meet the demands of the fuel market. The aim of the present study was to evaluate the effects of irrigation water salinity and nitrogen fertilization on the growth and production of castor beans, 'BRS Gabriela', in a protected environment. The present study was conducted at the Center of Technology and Natural Resources of the Federal University of Campina Grande. The experimental design was completely randomized in a $5 \times 4$ factorial with three replications and one plant per plot. The treatments consisted of irrigation water with five electrical conductivity (ECw) levels of $0.7,1.7,2.7,3.7$, and 4.7 $\mathrm{dS} \mathrm{m} \mathrm{m}^{-1}$ associated with four nitrogen levels of $60,80,100$, and $120 \mathrm{mg}$ of $\mathrm{N} \mathrm{kg}^{-1}$ of soil. The interaction between water salinity and nitrogen rates did not exert significant effects on the variables studied. Increased salinity of irrigation water affected the growth in height and stem diameter of castor beans in all periods, and leaf area from 90 days after sowing. Increased nitrogen levels had a positive effect on leaf area at $60,90,120$, and 150 days after sowing. The total mass of seeds, one hundred seed mass, yield, and number of fruits per plant decreased with the increase in water salinity, and the total mass of seeds was the most affected variable.
\end{abstract}

Key words: Ricinus communis L. Water salinity. Nitrogen.

\section{Resumo}

A mamoneira tem despertado atenção de muitos agricultores por ser mais uma alternativa para o Programa Nacional de Biocombustível e também por sua ampla utilização na indústria ricinoquímica, neste contexto a cultura exigirá grandes áreas de plantio para atender a demanda do mercado de

${ }^{1}$ Prof. Visitante, Universidade Federal de Campina Grande, UFCG, Centro de Ciências e Tecnologia Agroalimentar, CCTA, Pombal, PB, Brasil. E-mail: agrosantos@hotmail.com

${ }^{2}$ Prof. Visitante Nacional Sênior, CAPES, Universidade Federal do Recôncavo da Bahia, UFRB, Cruz das Almas, BA, Brasil. E-mail: hans@pq.cnpq.br

${ }^{3}$ Discente do Curso de Doutorado em Engenharia Agrícola, UFRB, Cruz das Almas, BA, Brasil. E-mail: klebsombrito@yahoo. com.br

${ }^{4}$ Discente do Curso de Mestrado em Engenharia Agrícola, UFCG, Centro de Tecnologia e Recursos Naturais Campina Grande, PB, Brasil. E-mail: daxengagricola@gmail.com

${ }^{5}$ Bolsista do Programa Nacional de Pós-Doutorado em Engenharia Agrícola, PNPD/CAPES, UFCG, Centro de Tecnologia e Recursos Naturais, Campina Grande, PB, Brasil. E-mail: geovanisoareslima@gmail.com

${ }^{6}$ Prof., Faculdade Mauricio de Nassau, UNINASSAU, Campina Grande, PB, Brasil. E-mail: cruzmarcen@gmail.com

${ }^{7}$ Prof., Departamento de Engenharia Agrícola, Universidade Federal Rural de Pernambuco, UFRPE, Recife, PE, Brasil. E-mail: manasses@dtr.ufrpe.br

* Author for correspondence 
combustíveis. Este estudo teve o objetivo de avaliar, em ambiente protegido, os efeitos da salinidade da água de irrigação e adubação nitrogenada sobre o crescimento e a produção da mamoneira, cultivar BRS Gabriela. O trabalho foi conduzido no Centro de Tecnologia e Recursos Naturais da Universidade Federal de Campina Grande. O delineamento estatístico foi inteiramente casualizado, em esquema fatorial $5 \times 4$, com três repetições e uma planta por parcela. Os tratamentos foram constituídos por cinco níveis de condutividades elétricas da água de irrigação (CEa), 0,$7 ; 1,7 ; 2,7 ; 3,7$ e 4,7 dS m${ }^{-1}$ associados a

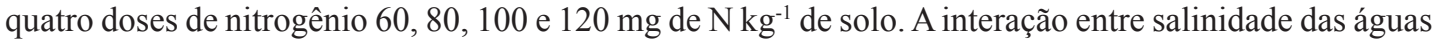
e doses de nitrogênio não exerceu efeitos significativos sobre as variáveis estudadas. O aumento da salinidade da água de irrigação prejudicou o crescimento em altura e o diâmetro de caule da mamoneira em todas as épocas avaliadas e a área foliar a partir dos 90 dias após a semeadura. $\mathrm{O}$ incremento das doses de nitrogênio exerceu efeito positivo sobre área foliar aos 60, 90,120 e 150 dias após a semeadura. A massa total e de cem sementes, rendimento em sementes e número de frutos planta ${ }^{-1}$ diminuiu com o aumento da salinidade da água de irrigação, sendo a massa total de sementes a variável mais afetada.

Palavras-chave: Ricinus communis. Água salina. Nitrogênio.

\section{Introduction}

The castor bean (Ricinus communis L.) is a drought-resistant plant belonging to the Euphorbiaceae family from tropical and semiarid regions (BELTRÃO et al., 2008). Given its socioeconomic value, the castor bean is an alternative crop for semiarid regions due to its wide use in the ricin industry and in fertilizer production. After the extraction of oil from the seeds, the cake generated as a byproduct is rich in N, P, and K (EMBRAPA, 2006). The oil is of great importance in many industrial sectors (FREIRE et al., 2006), with wide applications in cosmetics, pharmaceutical products, lubricants, and polymers (CHIERICE; CLARO NETO, 2007).

India is the largest castor bean producer in the world, producing more than 1,600,000 tons in 2013, well above China and Mozambique, both producing 60,000 tons, and above the Brazilian production, which sharply decreased after a long period of drought of more than a year, reaching a little less than 20,000 tons. The Brazilian northeast region contributes to approximately $90 \%$ of the national castor bean production and Bahia State, the largest producer, has a mean yield of $646 \mathrm{~kg} \mathrm{ha}^{-1}$ (CONAB, 2014).

With the establishment of the National Program for Production and Use of Biodiesel by the Federal Government in 2004, expansion in oilseed plant cultivation was stimulated in many regions of the country, aimed at the production of biodiesel, thereby contributing to the improvement of environmental quality through reduction in the air pollution index and dependence on petroleum (SANTOS et al., 2011). Unlike some oilseed plants, including peanut, sunflower, and soybean, the castor bean is not cultivated for human consumption; therefore, socioeconomically there is no competition with this market (PIRES et al., 2004).

Irrigation influences crop development and production greatly, because it minimizes the effects of drought and rainfall irregularity, which are typical edaphoclimatic conditions of arid and semiarid regions (OLIVEIRA et al., 2012). In these regions, the quality of irrigation water has high spatial and temporal variation, and water sources with high salt concentrations are common (BEZERRA et al., 2010).

High dissolved salt concentrations in soil solutions result in decreased crop growth and production capacity, due to reduced osmotic and total water potentials and the ionic effect of salt accumulation, since they directly affect plant water and nutrient availability (ALVES et al., 2011). However, the intensity of these effects depends on other factors, such as species, cultivar, crop phenological stage, salt types, intensity and duration of saline stress, crop management, irrigation water quality, and edaphoclimatic conditions (MUNNS; TESTER, 2008). 
Previous studies (CAMPOS et al., 2009; SOARES et al., 2012; NOBRE et al., 2013; SANTOS et al., 2013; LIMA et al., 2014a, 2014b) have shown the effects of irrigation water with high salinity on the cultivation of the castor bean cultivar, 'BRS Energia'. However, they are limited to water with different salinity levels; therefore, further studies are necessary, especially on the castor bean 'BRS Gabriela' cultivar, on the effect of nitrogen (N) levels and saline water, to mitigate the negative effects caused by saline stress.

In this context, mineral nutrition is an important environmental factor, and $\mathrm{N}$ is the most required nutrient by most agricultural crops (MILLER; CRAMER, 2004). According to Maathuis (2009), plant development is closely related to $\mathrm{N}$ supply, especially because this nutrient directly affects plant metabolism, as a constituent of chlorophyll, nucleic acids, amino acids, and proteins.

Thus, the present study aimed to evaluate growth and production of the castor bean 'BRS Gabriela' cultivar, under different irrigation water salinity levels and increasing doses of $\mathrm{N}$.

\section{Material and Methods}

The study was conducted from September 2012 to February 2013 in a greenhouse, at the Center of Technology and Natural Resources of the Federal University of Campina Grande (UFCG), Campus of Campina Grande, $7^{\circ} 13^{\prime} 50^{\prime}$ 'S and $35^{\circ} 52^{\prime} 52^{\prime}$ ' W, at a mean altitude of $550 \mathrm{~m}$.

The statistical design was completely randomized, in a $5 \times 4$ factorial scheme, with three replicates. The studied factors included five levels of salinity in the irrigation water (ECw: 0.7, 1.7, 2.7, 3.7, and $\left.4.7 \mathrm{dS} \mathrm{m}^{-1}\right)$ and four $\mathrm{N}$ doses $(60,80$, 100 , and $120 \mathrm{mg}$ of $\mathrm{N} \mathrm{kg}^{-1}$ of soil).

Water with the respective salinity levels was prepared by adding $\mathrm{NaCl}$, without iodate and with a purity of $99 \%$, to water from the local supply system

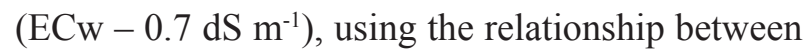

$\mathrm{ECw}$ and salt concentration in $\mathrm{mg} \mathrm{L}^{-1}$ proposed by Richards (1954).

The cultivar 'BRS Gabriela', produced by the Brazilian Agricultural Research Corporation (EMBRAPA), Campina Grande-PB, was used in the experiment; it has a cycle of 100 to 200 days. 'BRS Gabriela' was obtained from segregation and crosses between 'BRS Nordestina' and 'BRS Paraguaçu', and has the lowest height compared to its parental cultivars (MILANI; NOBREGA, 2012).

Sixty 200-L plastic pots were used, which were placed at a distance of $2.0 \mathrm{~m}$ between rows and $1.5 \mathrm{~m}$ between plants. A nylon mesh was placed at the bottom of the pots and covered with $5 \mathrm{~kg}$ of crushed stone (number zero). A plastic tube with 5 $\mathrm{mm}$ diameter was attached to the base of the pots for drainage and plastic bottles were placed below the pots to collect the leachate. The soil used to fill the pots was a non-saline, eutrophic Gray Argisol, according to the Brazilian Soil Classification System - SiBCS (EMBRAPA, 2013), from the Campina Grande municipality, collected from the 0-30 $\mathrm{cm}$ layer, pounded to break up clods, sieved, and placed in plastic pots of $240 \mathrm{~kg}$ capacity, avoiding excessive compaction (Table 1).

Phosphate fertilization was performed using a single superphosphate dose corresponding to 300 $\mathrm{mg}$ of $\mathrm{P}_{2} \mathrm{O}_{5} \mathrm{~kg}^{-1}$ of soil, as a basal application, 1 day before sowing. $\mathrm{N}$ fertilization was performed according to the treatments, $1 / 3$ at sowing and $2 / 3$ in equal applications at 20 and 40 days after sowing (DAS), using urea as the $\mathrm{N}$ source, applied with the irrigation water. Potassium fertilization, applied as potassium chloride (150 mg of $\mathrm{K}_{2} \mathrm{O} \mathrm{kg} \mathrm{kg}^{-1}$ of soil), was divided into three applications, similar to $\mathrm{N}$ fertilization. NPK fertilization was performed based on the recommendation of Novais et al. (1991) for pot experiments.

Six seeds were planted in each pot, at a depth of $1.0 \mathrm{~cm}$ and equidistantly distributed. The first thinning was performed 8 days after emergence, leaving 3 plants per pot, and the second thinning was 
performed 15 days after emergence, maintaining the soil was maintained at field capacity through daily most vigorous plant in each pot. After sowing, the irrigation.

Table 1. Chemical characteristics of the soil used in the experiment before treatment application.

\begin{tabular}{lclc}
\hline Chemical characteristics of the soil & Values & \multicolumn{1}{c}{ Soil saturation extract } & Values \\
\hline $\mathrm{pH}\left(\mathrm{H}_{2} \mathrm{O}\right)$ & 6.17 & $\mathrm{pH}$ & 5.97 \\
$\mathrm{OM}\left(\mathrm{g} \mathrm{kg}^{-1}\right)$ & 19.1 & ECse $\left.(\mathrm{dS} \mathrm{m})^{-1}\right)$ & 2.03 \\
$\mathrm{P}\left(\mathrm{mg} \mathrm{dm}^{-3}\right)$ & 56.2 & Chloride $\left(\mathrm{mmol}_{\mathrm{c}} \mathrm{L}^{-1}\right)$ & 12.5 \\
$\mathrm{Ca}^{2+}\left(\mathrm{cmol}_{\mathrm{c}} \mathrm{kg}^{-1}\right)$ & 3.88 & Bicarbonate $\left(\mathrm{mmol}_{\mathrm{c}} \mathrm{L}^{-1}\right)$ & 5.00 \\
$\mathrm{Mg}^{2+}\left(\mathrm{cmol}_{\mathrm{c}} \mathrm{kg}^{-1}\right)$ & 2.86 & Calcium $\left(\mathrm{mmol}_{\mathrm{c}} \mathrm{L}^{-1}\right)$ & 10.37 \\
$\mathrm{~K}^{+}\left(\mathrm{cmol}_{\mathrm{c}} \mathrm{kg}^{-1}\right)$ & 0.30 & Magnesium $\left(\mathrm{mmol}_{\mathrm{c}} \mathrm{L}^{-1}\right)$ & 9.63 \\
$\mathrm{Na}^{+}\left(\mathrm{cmol}_{\mathrm{c}} \mathrm{kg}^{-1}\right)$ & 0.47 & Potassium $\left(\mathrm{mmol}_{\mathrm{c}} \mathrm{L}^{-1}\right)$ & 0.38 \\
$\mathrm{Al}^{++}\left(\mathrm{cmol}_{\mathrm{c}} \mathrm{kg}^{-1}\right)$ & 0.00 & Sodium $\left(\mathrm{mmol}_{\mathrm{c}} \mathrm{L}^{-1}\right)$ & 4.86 \\
$\mathrm{H}^{+}\left(\mathrm{cmol}_{\mathrm{c}} \mathrm{kg}^{-1}\right)$ & 1.62 & SAR $\left(\mathrm{mmol} \mathrm{L}^{-1}\right)^{1 / 2}$ & 1.54 \\
$\mathrm{SB}\left(\mathrm{cmol}_{\mathrm{c}} \mathrm{kg}^{-1}\right)$ & 7.51 & & \\
$\mathrm{CEC}\left(\mathrm{cmol}_{\mathrm{c}} \mathrm{kg}^{-1}\right)$ & 9.13 & & \\
$\mathrm{~V}(\%)$ & 82.25 & & \\
$\mathrm{ESP}(\%)$ & 5.15 & & \\
\hline
\end{tabular}

$\mathrm{OM}$ - Organic matter; CEC - Cation exchange capacity - $\left.\mathrm{SB}+\left(\mathrm{H}^{+}+\mathrm{Al}^{3+}\right)\right] ; \mathrm{SB}-\mathrm{Sum}$ of bases $\left(\mathrm{Ca}^{2+}+\mathrm{Mg}^{2+}+\mathrm{K}^{+}+\mathrm{Na}^{+}\right) ; \mathrm{V}-\mathrm{Base}^{2}$ saturation $\%=(\mathrm{SB} / \mathrm{CEC}) \times 100 ;$ ECse - Electrical conductivity in the saturation extract; ESP - Exchangeable sodium percentage $\left(\mathrm{Na}^{+} / \mathrm{CEC} \times 100\right)$.

The applied water depth (VI) was estimated through the water balance in the root zone, by subtracting the volume drained in the previous irrigation (VD) from the applied volume (VA) (VI $=\mathrm{VA}-\mathrm{VD})$, thus obtaining the volume consumed by the plant and adding a leaching fraction of 0.10 to minimize salt accumulation. Although the equation does not consider direct measurement of soil evaporation or plant evapotranspiration, this methodology is adequate for maintaining soil with moisture content approximately equal to the field capacity and adequate leaching in the root zone under irrigation with water of increasing salinity (MESQUITA et al., 2012).

Plant growth in height, stem diameter, and leaf area were evaluated monthly. Plant height was measured from its base to the apical meristem using a steel tape. Stem diameter was measured using a digital caliper, $3 \mathrm{~cm}$ above the plant base. Leaf area was obtained by measuring the midrib length $(\mathrm{P})$ of each leaf, according to the methodology described by Severino et al. (2005), using the following equation:
$\mathrm{S}=\Sigma 0.26622 \times \mathrm{P}^{2.4248}$. At $150 \mathrm{DAS}$, the fruits of the primary raceme were counted, collected, processed, and separated from the husks; then, the total mass of seeds and the mass of 100 seeds were determined on a precision scale. The viable seeds and the husks were separated and weighed for the determination of seed yield using Eq. 1:

$$
\mathrm{SY}=\frac{(\mathrm{MS}-\mathrm{MH})}{\mathrm{MT}} \times 100
$$

where:

SY- Seed yield per plant (\%);

MS- Mass of seeds (g);

MH- Mass of husks (g); and

MT- Total mass of seeds (MS $+\mathrm{MH})$

The results were subjected to analysis of variance using the $F$ test at 0.01 and 0.05 probability levels. When the effects were significant, a regression analysis was performed using the statistical program 
SISVAR 4.2 (FERREIRA, 2011). Only first- and second-degree regressions were considered because of the biological explanation of the effects of the studied factors.

\section{Results and Discussion}

The $\mathrm{F}$ test results (Table 2) indicate that the interaction between water salinity and $\mathrm{N}$ doses did not interfere significantly $(p>0.05)$ with any of the growth variables. These results were consistent with those of Oliveira et al. (2006), Lima et al. (2012, 2014a). Despite the absence of significant effects of the interaction on castor bean growth in height and stem diameter, there were significant effects ( $p$ $<0.05$ ) of irrigation water salinity on all the studied variables except leaf area at 30 and 60 DAS and of $\mathrm{N}$ doses on leaf area from 60 to $150 \mathrm{DAS}$.

Table 2. Summary of the F test for plant height, stem diameter, and leaf area of the castor bean cultivar 'BRS Gabriela' at 30,60, 90, 120, and 150 days after sowing (DAS), cultivated under irrigation water salinity and nitrogen fertilization.

\begin{tabular}{|c|c|c|c|c|c|}
\hline \multirow{3}{*}{ Variation source } & \multicolumn{5}{|c|}{ F test } \\
\hline & \multicolumn{5}{|c|}{ 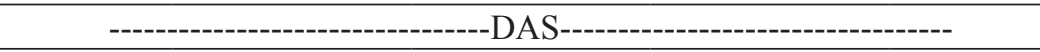 } \\
\hline & 30 & 60 & 90 & 120 & 150 \\
\hline \multicolumn{6}{|l|}{ Plant height } \\
\hline Salinity (S) & ** & ** & $* *$ & $* *$ & $* *$ \\
\hline Linear regression & $* *$ & $* *$ & $* *$ & $* *$ & $* *$ \\
\hline Quadratic regression & ns & ns & ns & ns & ns \\
\hline Nitrogen $(\mathrm{N})$ & ns & ns & ns & ns & ns \\
\hline Interaction $(\mathrm{S} \times \mathrm{N})$ & ns & ns & ns & ns & ns \\
\hline $\mathrm{CV}(\%)$ & 14.75 & 15.52 & 10.95 & 9.15 & 8.30 \\
\hline \multicolumn{6}{|l|}{ Stem diameter } \\
\hline Salinity (S) & $* *$ & $* *$ & $* *$ & $* *$ & $* *$ \\
\hline Linear regression & $* *$ & $* *$ & $* *$ & $* *$ & $* *$ \\
\hline Quadratic regression & ns & $\mathrm{ns}$ & ns & ns & $*$ \\
\hline Nitrogen $(\mathrm{N})$ & ns & $\mathrm{ns}$ & ns & ns & ns \\
\hline Interaction $(\mathrm{S} \times \mathrm{N})$ & ns & ns & ns & ns & ns \\
\hline CV $(\%)$ & 8.40 & 6.86 & 8.20 & 6.47 & 5.67 \\
\hline \multicolumn{6}{|l|}{ Leaf area } \\
\hline Salinity (S) & ns & $\mathrm{ns}$ & $* *$ & $* *$ & $* *$ \\
\hline Linear regression & ns & ns & $* *$ & $* *$ & $* *$ \\
\hline Quadratic regression & ns & ns & $* *$ & ns & ns \\
\hline Nitrogen $(\mathrm{N})$ & ns & $* *$ & $*$ & $* *$ & $* *$ \\
\hline Linear regression & ns & $* *$ & $*$ & $* *$ & $* *$ \\
\hline Quadratic regression & ns & ns & ns & ns & $* *$ \\
\hline Interaction $(\mathrm{S} \times \mathrm{N})$ & ns & ns & ns & ns & ns \\
\hline CV $(\%)$ & 12.09 & 10.61 & 7.22 & 7.04 & 6.89 \\
\hline
\end{tabular}

$\mathrm{ns}=$ not significant $*=$ significant $(\mathrm{p}<0.05) ; * *=$ significant $(\mathrm{p}<0.01) ; \mathrm{CV}=$ coefficient of variation.

Plant height decreased linearly as a function of the increase in irrigation water salinity, regardless of the evaluation period (Figure 1A). According to the equations adjusted to each period (30, 60, 90, 120 , and 150 DAS) as a function of the irrigation water salinity through the regression coefficients, plant height decreased by $8.14,10.69,12.03,13.46$, and $13.15 \%$, respectively, for each unit increase in electrical conductivity of the irrigation water (Figure 1A). Similar results were obtained by Lima et al. (2014a), who observed decreases of 5.6 and $5.0 \%$ at 60 and $120 \mathrm{DAS}$, respectively, in plant 
height of the castor bean cultivar 'BRS Energia' per unit increase in $\mathrm{ECw}$, which ranged from 0.3 to $3.9 \mathrm{dS} \mathrm{m}^{-1}$. Nobre et al. (2013), noted that the 'BRS Energia' castor bean irrigated with water with an electrical conductivity from 0.4 to $4.4 \mathrm{dS}$ $\mathrm{m}^{-1}$, showed a reduction in plant height of 5.05 and $6.01 \%$ per unit increase in $\mathrm{ECw}$ at 35 and $120 \mathrm{DAS}$, respectively.
The decrease in plant height is a consequence of the osmotic effect of dissolved salts, which restrict the osmotic potential of the soil solution and reduce water absorption in plants, resulting in nutritional imbalance and ionic toxicity, or both, due to the excessive accumulation of certain ions in plant tissues (FLOWERS, 2004).

Figure 1. Plant height (A) and stem diameter (B) of the castor bean cultivar 'BRS Gabriela' at 30, 60, 90, 120, and 150 days after sowing (DAS) as a function of irrigation water salinity.

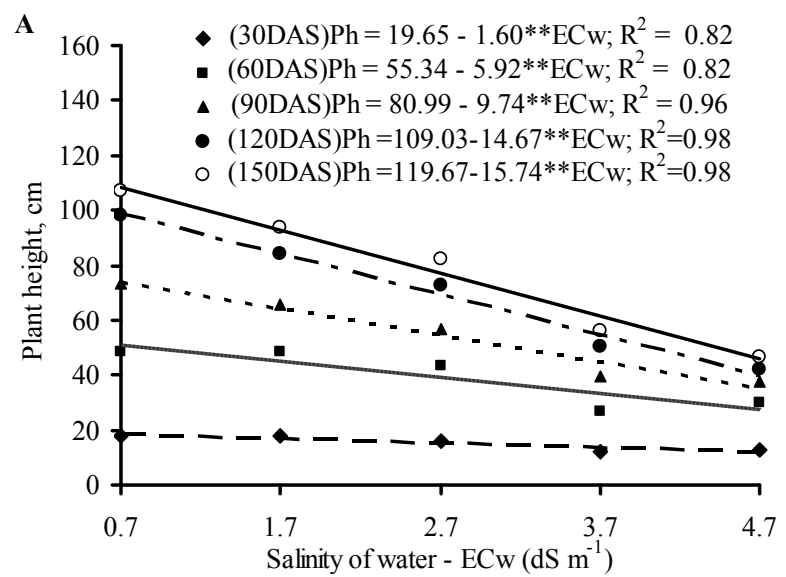

As observed for plant height, stem diameter also decreased linearly with increased in $\mathrm{ECW}$ at 30, 60, 90, 120 and 150 DAS, respectively. These results are consistent with those reported by Santos et al. (2013) who concluded that stem diameter of 'BRS Energia' castor bean revealed a moderately water salinity. Based on the regression equations (Figure 1B), there were reductions of $6.65,8.95$, $9.12,10.59$, and $10.6 \%$ per unit increase sensitive character under irrigation with saline water, with an electrical conductivity from 0.8 to $4.8 \mathrm{dS} \mathrm{m}^{-1}$.

Leaf area also decreased and fitted a linear regression model (Figure 2A). Ayers and Westcot (1999) explained that as soil salinity increases, water

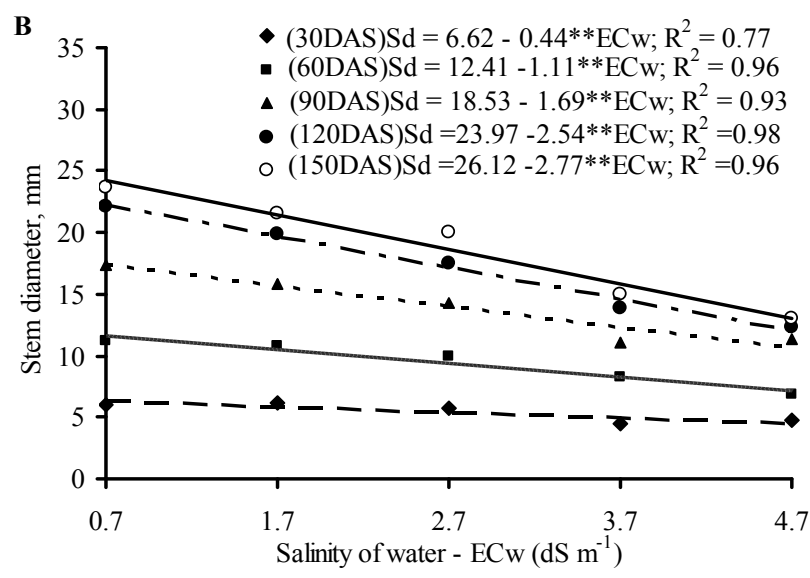

availability to crops decreases, and under these conditions plants require more energy to absorb water from the soil, which causes reduced growth. This was observed by Lima et al. (2007), who studied the influence of saline water on soil physicochemical characteristics and on the development of the 'BRS Energia' castor bean cultivated in pots.

Regression analysis revealed a decreasing linear effect of irrigation water salinity on leaf area at 90, 120 , and 150 DAS, with respective decrease of $1,558,3,559$, and $3,313 \mathrm{~cm}^{2}$ representing reduction of $17.5,18.9 \%$, and $19.4 \%$ in plant leaf area with per unit increase in ECw (Figure 2A). Among the evaluated growth variables, leaf area is most sensitive to increase in irrigation water salinity. 
Figure 2. Leaf area of the castor bean cultivar 'BRS Gabriela' as a function of irrigation water salinity at 90, 120, and 150 days after sowing (DAS) (A) and nitrogen fertilization at 60, 90, 120, and 150 DAS (B).

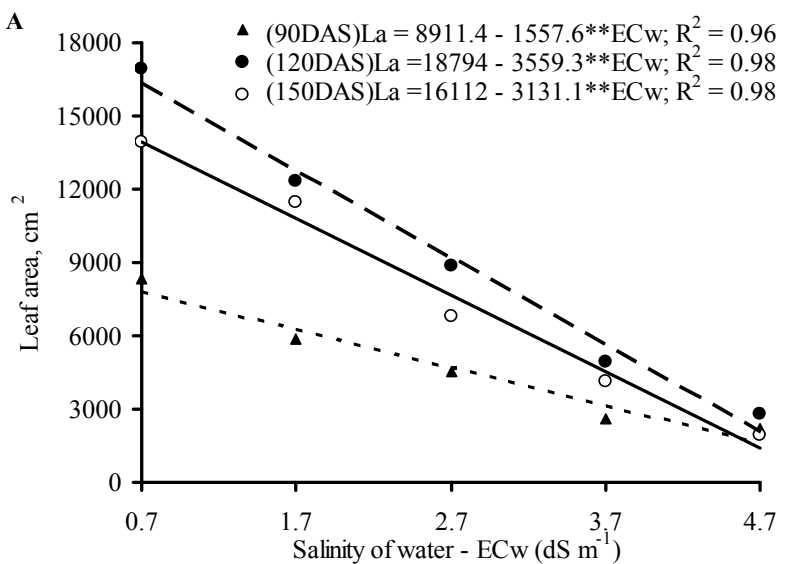

Reduction in leaf area of plants under salinity conditions (TESTER; DAVENPORT, 2003), expresses an important adaptive mechanism, because under these conditions, transpiration is reduced and consequently, the transport of $\mathrm{Na}^{+}$and $\mathrm{Cl}^{-}$ions in the xylem is decreased, and a high water potential is maintained in the plant. Decreased leaf area under saline stress has also been reported by Soares et al. (2012), who observed a reduction in leaf area of $11.76 \%$ per unit salinity increase at 88 DAS in the cultivar 'BRS Energia' irrigated with increasing water salinity levels from 0.4 to $4.4 \mathrm{dS}$ $\mathrm{m}^{-1}$, and also by Lima et al. (2014a), who observed a leaf area reduction of $17 \%$ per unit increase in $\mathrm{ECW}$ for the castor bean cultivar 'BRS Energia', with increased salinity from 0.3 to $3.9 \mathrm{dS} \mathrm{m}^{-1}$.

$\mathrm{N}$ doses resulted in increase in leaf area. The regression equation (Figure $2 \mathrm{~B}$ ), showed that leaf area increased linearly as a function of increased $\mathrm{N}$ fertilization, with increments of 48.27, 6.18, 5.15\%, and $6.08 \%$ at $60,90,120$, and $150 \mathrm{DAS}$, respectively, for each $20 \mathrm{mg}$ of $\mathrm{N} \mathrm{kg}^{-1}$ of soil. Additionally, based on the regression analysis, the highest growth in leaf area occurred at 120 DAS and plants fertilized with $120 \mathrm{mg}$ of $\mathrm{N} \mathrm{kg}^{-1}$ of soil showed increases of 2,278 $\mathrm{cm}^{2}$ in leaf area, compared with plants fertilized with $60 \mathrm{mg}$ of $\mathrm{N} \mathrm{kg}^{-1}$. Alves et al. (2012) observed no significant effect on leaf area of the castor bean

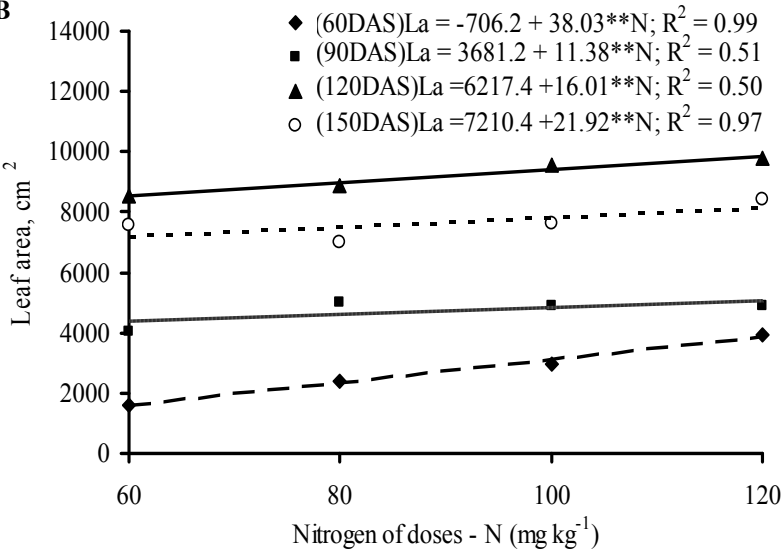

cultivar 'BRS Energia', after applying $\mathrm{N}$ doses from 50 to $150 \%$ of the dose recommended by Novais et al. (1991). This difference in response is probably related to the amount of $\mathrm{N}$ applied, because in the study developed by Alves et al. (2012), at 40 DAS, only part of the $\mathrm{N}$ had been applied, contrary to the present study, in which all $\mathrm{N}$ fertilization had been applied at 60 DAS. The results of the present study are similar to those reported by Nobre et al. (2013), who studied the effects of $\mathrm{N}$ fertilization, with doses of 50 to $150 \%$ of the dose recommended by Novais et al. (1991) for pot experiments on the castor bean cultivar 'BRS Energia'.

As observed for growth (Table 3), the interaction between irrigation water salinity and $\mathrm{N}$ doses had no significant effect on the production components of the castor bean cultivar 'BRS Gabriela'. In addition, all the variables were influenced $(p<0.01)$ by irrigation water salinity and did not respond to the effects of $\mathrm{N}$ doses (Table 3 ).

According to the regression equation, with the increase in water salinity, a reduction of $21.26 \%$ in the total mass of seed per plant (Figure 3A) per unit increase in ECW was observed. There was a difference of $99.91 \%$ between the salinity levels of 0.7 and $4.7 \mathrm{dS} \mathrm{m}^{-1}$, which shows that the total mass of seeds was negatively affected by the increase in 
irrigation water salinity, according to the regression equation. Lima et al. (2012) observed that the increase in ECW resulted in a linear decrease on the mass of seeds of the castor bean cultivar 'BRS Energia', with an approximately $17 \%$ per unit increase in electrical conductivity of the irrigation water.
Similar losses were reported by Silva et al. (2008), who studied the growth of the castor bean cultivars 'BRS Paraguaçu' and 'BRS Energia' and observed a difference of $96.8 \%$ in the seed mass, for both cultivars, when the highest salinity level (4.7 $\left.\mathrm{dS} \mathrm{m}^{-1}\right)$ was compared with the lowest one $(0.7 \mathrm{dS}$ $\left.\mathrm{m}^{-1}\right)$.

Table 3. Summary of the F test for total mass of seeds (TMS), mass of 100 seeds (MHS), seed yield (SY) and number of fruits per plant (NFP) at 150 days after sowing of castor bean, cultivated with varying irrigation water salinity and nitrogen doses.

\begin{tabular}{lcccc}
\hline \multirow{2}{*}{ Variation source } & \multicolumn{3}{c}{ F test } & \\
\cline { 2 - 5 } & TMS & MHS & SY & NFP \\
\hline Salinity (S) & $* *$ & $* *$ & $* *$ & $* *$ \\
Linear regression & $* *$ & $* *$ & $* *$ & $* *$ \\
Quadratic regression & $* *$ & $*$ & $*$ & $* *$ \\
Nitrogen (N) & $\mathrm{ns}$ & $\mathrm{ns}$ & $\mathrm{ns}$ & $\mathrm{ns}$ \\
Linear regression & $\mathrm{ns}$ & $\mathrm{ns}$ & $\mathrm{ns}$ & $\mathrm{ns}$ \\
Quadratic regression & $\mathrm{ns}$ & $\mathrm{ns}$ & $\mathrm{ns}$ & $\mathrm{ns}$ \\
Interaction $(\mathrm{S} \mathrm{x} \mathrm{N)}$ & $\mathrm{ns}$ & & & $\mathrm{ns}$ \\
\hline
\end{tabular}

$\mathrm{ns}$, not significant; *significant $(\mathrm{p}<0.05)$; ** significant $(\mathrm{p}<0.01)$.

Figure 3. Total mass of seeds (A) and mass of 100 seeds (B) of the castor bean cultivar 'BRS Gabriela' as a function of irrigation water salinity, at harvest.

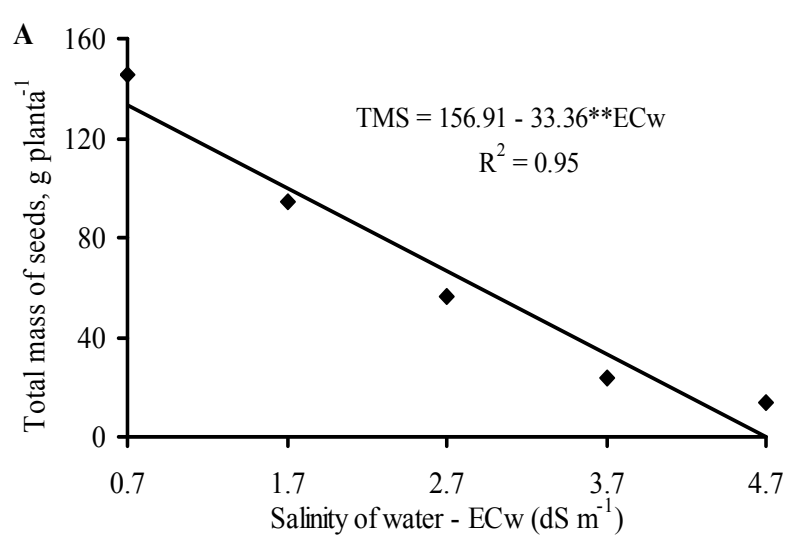

The increase in irrigation water salinity reduced (10.01\% per unit increase in $\mathrm{ECw})$ the mass of 100 seeds - MHS (Figure 3B), with values of 56.8, $50.67,44.55,38.44$, and $32.32 \mathrm{~g}$, respectively, for plants irrigated with water of $0.7,1.7,2.7,3.7$, and

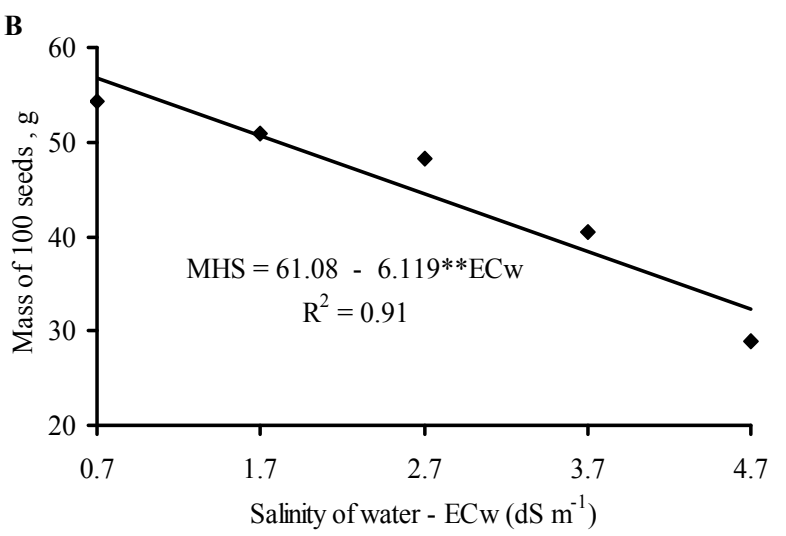

$4.7 \mathrm{dS} \mathrm{m}^{-1}$, evidencing that irrigation water salinity negatively influenced this variable. According to Nobre et al. (2012), castor bean growth and production are affected by irrigation water salinity above $0.4 \mathrm{dS} \mathrm{m}^{-1}$. 
For seed yield, the increase in salinity of the irrigation water increased the husk mass in relation to the seed mass, promoting seed yield of 74.09 , $70.71,67.09,63.95$, and $60.57 \%$, respectively, for plants irrigated with water of $0.7,1.7,2.7,3.7$, and $4.7 \mathrm{dS} \mathrm{m}^{-1}$ (Figure 4A), with a decrease of $4.42 \%$ per unit increase in $\mathrm{ECw}$, indicating that irrigation water salinity had little influence on this variable.
The number of fruits per plant (Figure 4B) decreased by $19.96 \%$ per unit increase in irrigation water salinity. There was a reduction of $92.80 \%$ between plants subjected to the highest $(4.7 \mathrm{dS}$ $\left.\mathrm{m}^{-1}\right)$ and lowest $\left(0.7 \mathrm{dS} \mathrm{m}^{-1}\right)$ salinity levels. Nobre et al. (2012), evaluating oil content and yield of 'BRS Energia' castor beans irrigated with water of different $\mathrm{ECw}$ levels ( 0.4 to $4.4 \mathrm{dS} \mathrm{m}^{-1}$ ), also observed decrease in the fruit number equivalent to $17.98 \%$ per unit increase in $\mathrm{ECW}$.

Figure 4. Seed yield (A) and number of fruits per plant (B) of the castor bean cultivar 'BRS Gabriela' as a function of irrigation water salinity, at harvest.

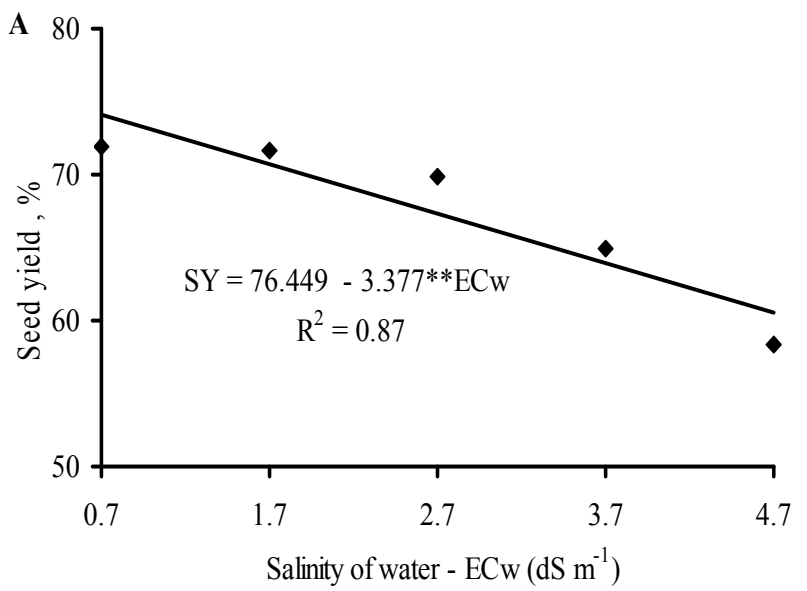

\section{Conclusions}

1. The interaction between water salinity and nitrogen doses had no significant effect on the studied variables.

2. The increase in irrigation water salinity negatively affected castor bean growth in terms of height and stem diameter in all the evaluated periods and its leaf area from 90 days after sowing.

3. The increment in nitrogen doses had a positive effect on leaf area at 60, 90, 120, and 150 days after sowing.

4. Total mass of seeds, mass of 100 seeds, seed yield, and number of fruits per plant decreased with an increase in irrigation water salinity, and the total mass of seeds was the most affected variable.

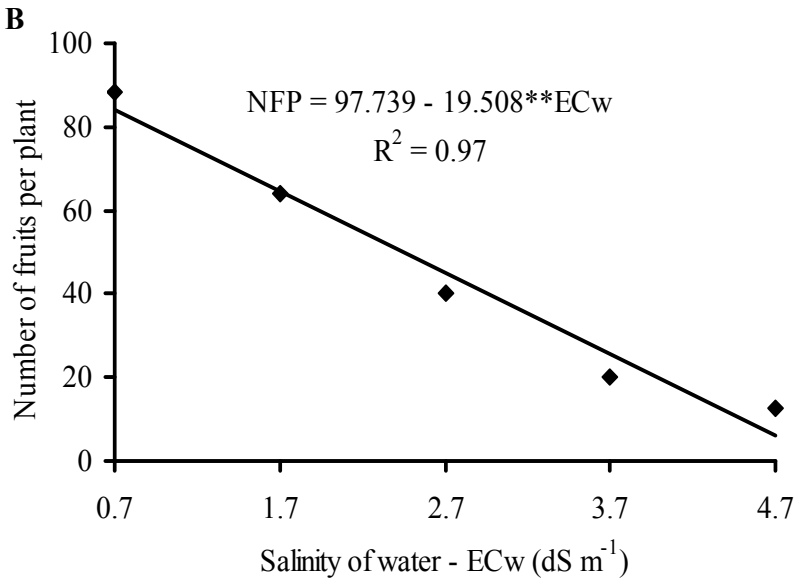

\section{References}

ALVES, A. N.; GHEYI, H. R.; UYEDA, C. A.; SOARES, F. A. L.; NOBRE, R. G.; CARDOSO, J. A. F. Uso de águas salinas e adubação nitrogenada no cultivo da mamoneira BRS-Energia. Revista Brasileira de Agricultura Irrigada, Fortaleza, v. 6, n. 2, p. 151-163, 2012.

ALVES, F. A. L.; FERREIRA-SILVA, S. L.; SILVEIRA, J. A. G. da; PEREIRA, V. L. Efeito do $\mathrm{Ca}^{2+}$ externo no conteúdo de $\mathrm{Na}^{+}$e $\mathrm{K}^{+}$em cajueiros expostos a salinidade. Revista Brasileira de Ciências Agrárias, Recife, v. 6, n. 4, p. 602-608, 2011.

AYERS, R. S.; WESTCOT, D. W. A qualidade da água na agricultura. Campina Grande: UFPB, 1999. 218 p. (Estudos FAO: Irrigação e Drenagem, 29, revisado 1).

BELTRÃO, N. E. de M.; VALE, L. S. do; SILVA, O. R. F. da. Grãos oleaginosos. In: ALBUQUERQUE, A. C. S.; SILVA, A G. da. Agricultura tropical: quatro décadas de inovações tecnológicas, institucionais e políticas. 1. 
Produção e produtividade agrícola. Brasília: EMBRAPA Informação Tecnológica. 2008. cap. 4. p. 753-766.

BEZERRA, A. K. P.; LACERDA, C. F. de; HERNANDEZ, F. F. F.; SILVA, F. B. da; GHEYI, H. R. Rotação cultural feijão caupi/milho utilizando-se águas de salinidades diferentes. Revista Ciência Rural, Santa Maria, v. 40, n. 5, p. 1075-1082, 2010.

CAMPOS, V. B.; CAVALCANTE, L. F.; RODOLFO JÚNIOR. F.; SOUSA, G. G.; MOTA, J. K. Crescimento inicial da mamoneira em resposta à salinidade e biofertilizante bovino. Magistra, Cruz das Almas, v. 21, n. 1, p. 41-47, 2009.

CHIERICE, G. O.; CLARO NETO, S. Aplicação industrial do óleo. In: AZEVEDO, D. M. P.; BELTRÃ̃, N. E. M. (Ed.). O agronegócio da mamona no Brasil. 2. ed. Brasília: Embrapa Informação Tecnológica, 2007. p. 417-447.

COMPANHIA NACIONAL DE ABASTECIMENTO CONAB. $7^{\circ}$ Levantamento da safra 2013/2014. Brasília, 2014. 6p. Disponível em: <http://www.conab.gov.br>. Acesso em: 20 ago. 2014.

EMPRESA BRASILEIRA DE PESQUISA AGROPECUÁRIA - EMBRAPA. Centro Nacional de Pesquisa de Solos. Sistema brasileiro de classificação de solos. 3. ed. Rio de Janeiro: Embrapa Informação Tecnológica, 2013. 353 p.

Centro Nacional de Pesquisa do Algodão. Produto: mamona. Campina Grande: Embrapa Algodão, 2006. 62 p. Disponível em: <http://www.cnpa.embrapa. br/produtos/mamona/publicações $>$. Acesso em: 27 set. 2015.

FERREIRA, D. F. Sisvar: a computer statistical analysis system. Ciência e Agrotecnologia, Lavras, v. 35, n. 6, p. 1039-1042, 2011.

FLOWERS, T. J. Improving crop salt tolerance. Journal of Experimental Botany, Oxford, v. 55, n. 396, p. 307319, 2004.

FREIRE, R. M. M.; SEVERINO, L. S.; MACHADO, O. L. T. Ricinoquimica e co-produtos. In: AZEVEDO, D. M. P.; BELTRAO, N. E. M. (Ed.). O agronegócio da mamona no Brasil. Brasilia: Embrapa Informação Tecnológica, 2006. cap. 13, p. 449-474.

LIMA, C. B.; SANTOS FILHO, S. V. dos; SANTOS, M. A.; OLIVEIRA, M. de. Influência da água salina nas características físicoquímicas do solo e no desenvolvimento da mamoneira cultivada em vasos. Revista Caatinga, Mossoró, v. 20, n. 4, p. 132-136, 2007.

LIMA, G. S. de; NOBRE, R. G.; GHEYI, H. R.; SOARES, L. A. dos A.; LOURENÇO, G. da S. Resposta da mamoneira cv. BRS Energia a diferentes níveis de salinidade da água e doses de nitrogênio. Revista Verde de Agroecologia e Desenvolvimento Sustentável, Mossoró, v. 7, n. 2, p. 79-87, 2012.

LIMA, G. S. de; NOBRE, R. G.; GHEYI, H. R.; SOARES, L. A. dos A.; LOURENÇO, G. da S.; SILVA, S. S. da. Aspectos de crescimento e produção da mamoneira irrigada com águas salinas e adubação nitrogenada. Revista Brasileira de Engenharia Agrícola e Ambiental, Campina Grande, v. 18, n. 6, p. 615-622, 2014a.

LIMA, G. S. de; NOBRE, R. G.; GHEYI, H. R.; SOARES, L. A. dos A.; SILVA, S. S. da. Respostas morfofisiológicas da mamoneira, em função da salinidade da água de irrigação e adubação nitrogenada. Irriga, Botucatu, v. 19, n. 1, p. 130-136, 2014 b.

MAATHUIS, F. J. M. Physiological functions of mineral macronutrients. Current Opinion in Plant Biology, Amsterdam, v. 12, n. 3, p. 250-258, 2009.

MESQUITA, F. O.; CAVALCANTE, L. F.; PEREIRA, W. E.; REBEQUI, A. M.; LIMA NETO, A. J.; NUNES, J. C. Produção de mudas de maracujazeiro amarelo submetidas à salinidade em solo com biofertilizante bovino. Ciência del Suelo, Ciudad Autónoma de Buenos Aires, v. 30, n. 1, p. 31-41, 2012.

MILANI, M.; NOBREGA, M. B. de M. BRS Gabriela. Campina Grande: Embrapa Algodão, 2012. 2p. (1 folder).

MILLER, A. J.; CRAMER, M. D. Root nitrogen acquisition and assimilation. Plant and Soil, Dordrecht, v. 274, n. 1, p. 3-6, 2004.

MUNNS, R.; TESTER, M. Mechanism of salinity tolerance. Annual Review of Plant Biology, Palo Alto, v. 59, n. 1, p. 651-681, 2008.

NOBRE, R. G.; LIMA, G. S. de; GHEYI, H. R.; LOURENÇO, G. S.; SOARES, L. A. Emergência, crescimento e produção da mamoneira sob estresse salino e adubação nitrogenada. Revista Ciência Agronômica, Fortaleza, v. 44, n. 1, p. 76-85, 2013.

NOBRE, R. G.; LIMA, G. S. de; GHEYI, H. R.; MEDEIROS, E. P. de; SOARES, L. A.; ALVES, N. A. Teor de óleo e produtividade da mamoneira de acordo com a adubação nitrogenada e irrigação com água salina. Pesquisa Agropecuária Brasileira, Brasília, v. 47, n. 7, p. 991-999, 2012.

NOVAIS, R. F.; NEVES, J. C. L.; BARROS, N. F. Ensaio em ambiente controlado. In: OLIVEIRA, A. J. (Ed.). Métodos de pesquisa em fertilidade do solo. Brasília: Embrapa/SEA, 1991. p. 189-253. 
OLIVEIRA, F. de A. de; MEDEIROS, J. F. de; OLIVEIRA, F. R. A. de; OLIVEIRA, M. K. T. de; FREIRE, A. G. Sensibilidade do algodoeiro ao cloreto de mepiquat em condições salinas. Revista Ciência Agronômica, Fortaleza, v. 43, n. 3, p. 484-492, 2012.

OLIVEIRA, M. K. T.; OLIVEIRA, F. de A. de; MEDEIROS, J. F. de; LIMA, C. J. G. de S; GUIMARÃES, I. P. Efeito de diferentes teores de esterco bovino e níveis de salinidade no crescimento inicial da mamoneira (Ricinus communis L.). Revista Verde de Agroecologia e Desenvolvimento Sustentável, Mossoró, v. 1, n. 1, p. 47-53, 2006.

PIRES, M. de M.; ALVES, J. M.; ALMEIDA NETO, J. A. de; ALMEIDA, C. M.; SOUSA, G. S. de; CRUZ, R. S. da; MONTEIRO, R.; LOPES, B. S.; ROBRA S. Biodiesel de mamona: uma avaliação econômica. In: CONGRESSO BRASILEIRO DA MAMONA, 1., 2004, Campina Grande. Anais... Campina Grande: Embrapa Algodão, 2004. CD-ROM.

RICHARDS, L. A. (Ed.). Diagnosis and improvement of saline and alkali soils. Washington, DC: U.S.D.A., 1954. 160 p. (Handbook, n. 60).

SANTOS, J. B. dos; SANTOS, D. B. dos; AZEVEDO, C. A. V. de; REBEQUI, A. M.; CAVALCANTE, L. F.; CAVAlCANTE, I. H. L. Comportamento morfofisiológico da mamoneira BRS Energia submetida à irrigação com água salina. Revista Brasileira de Engenharia Agrícola e Ambiental, Campina Grande, v. 17, n. 2, p. 145-152, 2013.
SANTOS, V. M.; CASTRO, H. G.; CARDOSO, D. P.; LIMA, S. O.; LEAL, T. C. A. B.; SANTOS, G. R. Avaliação do crescimento e da produtividade da mamoneira BRS 149, Nordestina em dois níveis tecnológicos. Journal of Biotechnology and Biodiversity, Gurupi, v. 2, n. 3, p. 58-66, 2011.

SEVERINO, L. S.; VALE, L. S.; CARDOSO, G. D.; BELTRÃO, N. E. de M.; SANTOS, J. W. dos. Método para determinação da área foliar da mamoneira. Campina Grande: Embrapa CNPA, 2005. 20 p. (Boletim de Pesquisa e Desenvolvimento, 55).

SILVA, S. M. S.; ALVES, A. N.; GHEYI, H. R.; BELTRÃO, N. E. de M.; SEVERINO, L. S.; SOARES, F. A. L. Desenvolvimento e produção de duas cultivares de mamoneira sob estresse salino. Revista Brasileira de Engenharia Agrícola e Ambiental, Campina Grande, v. 12, n. 4, p. 335-342, 2008.

SOARES, L. A. A.; NOBRE, R. G.; GHEYI, H. R.; LIMA, G. S.; SILVA, A. O.; SOARES, S. S. Componentes de crescimento da mamoneira cultivada com águas salinas e doses de nitrogênio. Irriga, Botucatu, v. 1, n. 1, p. 4054, 2012.

TESTER, M.; DAVENPORT, R. $\mathrm{Na}^{+}$tolerance and $\mathrm{Na}^{+}$ transport in higher plants. Annals of Botany, Oxford, v. 91, n. 5, p. 503-527, 2003. 
